\section{Economic impact of localized cutaneous leishmaniasis on adult patients of a referral service in Belo Horizonte, Minas Gerais State, Brazil}

\author{
Impacto econômico da leishmaniose cutânea \\ localizada em pacientes adultos em um \\ serviço de referência em Belo Horizonte, \\ Minas Gerais, Brasil
}
Impacto económico de la leishmaniosis cutánea localizada que afecta a pacientes adultos en un servicio de referencia en Belo Horizonte, Minas Gerais, Brasil




\section{Introduction}

Cutaneous leishmaniasis (CL) is a group of dermatological diseases caused by protozoans of the genus Leishmania, whose clinical manifestation depends on the involved species and their interaction with the host. Localized CL corresponds to around 70\% of the disease cases in the New World 1 . The World Health Organization (WHO) recognizes CL, alongside 19 other infectious diseases, as a neglected tropical disease (NTD). It is also referred as "infectious disease of poverty" 2 for its occurrence in lowincome countries: $90 \%$ of its cases are concentrated in Brazil, Afghanistan, Algeria, Pakistan, Peru, Saudi Arabia, and Syria 3.

In Brazil, the Ministry of Health reported 220,816 CL cases between 2007 and 2017 (Departamento de Informática do SUS. Leishmaniose tegumentar americana: casos confirmados notificados no Sistema de Informação de Agravos de Notificação - Brasil. http://tabnet.datasus.gov.br/cgi/tab cgi.exe?sinannet/cnv/ltabr.def, accessed on 01/Feb/2019), among which $27 \%$ of affected people were aged up to 19 years and $73 \%$ were adults. In Minas Gerais, during the same period, this proportion was $22 \%$ and $78 \%$, respectively. Unlike other NTDs, CL incidence is increasing 4 and its burden, estimated by disability-adjusted life years (DALYs), is still significantly unequal, being higher in South America, the Middle East, North Africa, and the Caribbean 5. Among South American countries, Brazil is ranked 5th, with DALY of 1.5 per 100,000 inhabitants (Institute for Health Metrics and Evaluation. GBD compare. http://vizhub.healthdata.org/gbd-compare, accessed on 10/Apr/2019).

CL duration tends to be higher in patients with indicators of lower socioeconomic status, and plays a role in impoverishing the affected populations 6 . Many countries guarantee access to public health care. Yet, some families report significant expenses with leishmaniasis diagnosis and treatment, not covered by their country health systems 7 . A recent study conducted in Sri Lanka reported a mean economic loss for households at completion of CL treatment of USD 76.59, about $5.4 \%$ of the annual household income and $20.9 \%$ of the mean annual per capita income of the study population 8 .

The association between socioeconomic factors and CL morbidity has been poorly documented, and studies addressing CL economic burden from the perspective of patients and health services are scarce 9. Acquiring evidence that helps understanding patients' economic vulnerability to a CL episode may underpin strategies to reduce the disease's economic impact for patients and their families 9 , as well as subsidize public policies and guide the proper allocation of resources. This study aimed to describe direct medical and non-medical costs of CL patients attended at a referral service in the state of Minas Gerais, Brazil.

\section{Methods}

The economic evaluation was part of a larger project for developing and validating a questionnaire to assess CL impact on patients. The study was conducted in the René Rachou Institute, Oswaldo Cruz Foundation (Fiocruz), in Belo Horizonte, Minas Gerais State, Brazil, a referral center for leishmaniasis 10,11. This study presents CL-related direct medical and non-medical costs from a societal perspective. Data were collected between 2015 and 2017 by interviewing patients, using a structured questionnaire, and gathering clinical and sociodemographic data available in medical records. The study population was the same of the validation study by the questionnaire regarding CL impact: adult patients, with confirmed CL diagnosis, and who started CL treatment from five to 90 days prior to the study.

The questionnaire included sociodemographic characteristics, such as gender, age, education level, occupation, marital status, and city of origin. The interview collected information on aspects of care and assistance, including the amount of visited health centers and medical appointments necessary to diagnose CL, the complexity degree of the service where CL was diagnosed, and approximate distance from patients' residence to the service of diagnosis and treatment. From medical records we acquired clinical aspects related to: lesion amount, body location, characteristics, and recurrence; dates of diagnosis and first definitive treatment; and medication protocol.

To analyze financial cost, monthly household income and monthly per capita income were recorded during the interview. Then, all costs CL-related were evaluated, considering the period from CL symptoms start to the interview date, and stratified into the following items: medical, hospitalization, 
medical exams, medications, transportation, food, patient's and children's caregivers, domestic and business outsourcing services, dressing material, and co-participation in private health insurance. Patients were encouraged to report other costs related to the disease. We documented the monetary value of each patient's expenses and converted it from Brazilian Reais (BRL) into US dollars (USD) at the exchange rate on the 1st of February, 2018 (USD $1.00=$ BRL 3.21).

The mean CL monthly economic impact was calculated considering the ratio between the patient's average expense with CL and the average time from diagnosis to interview. Descriptive statistics and frequency distribution (including mean, standard, and percentage) were employed. Non-parametric tests evaluated the differences among CL costs medians for patients across demographic, economic, and clinical characteristics. P-value $<0.05$ was considered as statistically significant. The related analysis of the questionnaire omitted incomplete answers. All analyses were performed by SPS 22.0 (https://www.ibm.com).

This research was conducted in accordance with Resolution n. 466/2012 of the Brazilian National Health Council and was approved by the Ethics Committee on Human Research of the René Rachou Institute (n. 1.337.731). All participants agreed to participate in the study by signing an Informed Consent Form.

\section{Results}

This study included one hundred patients with localized CL. Most of them were male (71\%), with at least primary education (54\%), and 49\% were either sellers or service providers with mean age of 45 years ( \pm 16 years). Half of these patients were from the metropolitan area of Belo Horizonte and the other half from the countryside of Minas Gerais. Regarding clinical aspects, 69 patients presented a single lesion and 31 two or more, and most lesions were ulcerated (83\%). All patients were treated with meglumine antimoniate: $52 \%$ using the intralesional route and $48 \%$ the intravenous route.

As for diagnosis, only $13 \%$ were diagnosed for CL in the first medical appointment; patients often had to visit between one and six health centers until diagnostic confirmation, with a mean of $2.54 \pm 1.13$ centers. The mean number of appointments until diagnosis was $4.22 \pm 2.50$. The majority of patients (84\%) was diagnosed with CL at the Leishmaniasis Reference Center. The mean time between symptoms start and the first medical appointment at the reference center was 108 days $( \pm$ 92 ), and the mean time between the first appointment and the interview was 42 days. To obtain diagnosis, $65 \%$ of the patients had to travel more than $30 \mathrm{~km}$, while $42 \%$ had to walk at least $30 \mathrm{~km}$ daily or weekly, depending on the therapeutic approach. Patients reported that they had to leave home on average 8.24 times $( \pm 6.50)$ to receive treatment until the interviews. Table 1 shows the main sociodemographic characteristics of patients and therapeutic approaches.

The mean monthly household income was USD 1,043.22 \pm 979.15 (BRL 3,348.76 \pm 3,143.09), and the mean per capita income USD $347.39 \pm 326.41$ (BRL 1,115.14 \pm 1,047.80), but the variable of income distribution was unequal: $50 \%$ of patients reported household income up to USD 778.81 (BRL 2,500.00) and per capita income up to USD 259.60 (BRL 833.33). Two patients reported being unemployed and having no income. The highest per capita income was USD 1,557.63 (BRL 5,000.00), reported only by two patients. Eleven patients omitted their monthly income. $50 \%$ of patients reported four days of work absence due to CL; one patient had to be absent from work for 240 days. We also found that while $38 \%$ of patients had a health insurance, $26.3 \%$ of them did not use it for CL-related medical appointments or exams. In a societal perspective, the mean costs of total treatment, including direct medical and non-medical costs, was USD 187.32 (BRL 601.31). Thus, CL had an average impact of USD 133.80 (BRL 429.50) on patient's monthly income. Table 2 shows the details of direct medical and non-medical costs from patients' perspective.

The main expenses regarded transportation for medical appointments, treatment, and complementary exams, totalizing USD 4,911.00 (BRL 15,764.80). Among the means of transport, 40\% of patients reported using their own cars and $24 \%$ depending on the public transportation provided by the department of public health of their county. The second main expense was food, which estimated total cost was USD 3,259.00 (BRL 10,463.00). Figure 1 illustrates expenditures in categories, according to CL estimated total costs reported by patients. 
Table 1

Sociodemographic and disease related characteristics and treatment approach of patients with cutaneous leishmaniasis (CL).

\begin{tabular}{|c|c|}
\hline Characteristics & $N=100$ \\
\hline \multicolumn{2}{|l|}{ Age (years) } \\
\hline $18-30$ & 26 \\
\hline $31-42$ & 25 \\
\hline $43-58$ & 26 \\
\hline $59-81$ & 23 \\
\hline \multicolumn{2}{|l|}{ Gender } \\
\hline Female & 29 \\
\hline Male & 71 \\
\hline \multicolumn{2}{|l|}{ Highest education level completed * } \\
\hline Primary education & 54 \\
\hline Secondary education & 27 \\
\hline Higher education & 19 \\
\hline \multicolumn{2}{|l|}{ Occupation } \\
\hline Sellers or service providers & 49 \\
\hline Rural workers & 19 \\
\hline Health professionals & 5 \\
\hline Public Servers & 2 \\
\hline Retired or pensioners & 14 \\
\hline Household workers & 4 \\
\hline Students & 3 \\
\hline Unemployed & 2 \\
\hline \multicolumn{2}{|l|}{ Family income (USD) *,** } \\
\hline $0-390.65$ & 23 \\
\hline $390.96-624.29$ & 18 \\
\hline $624.61-2,691.58$ & 42 \\
\hline 2,691.90-3,508.09 & 3 \\
\hline More than 3,508.41 & 3 \\
\hline \multicolumn{2}{|l|}{ Per capita income (USD) $*, \star \star *$} \\
\hline $0-390.65$ & 64 \\
\hline $390.96-624.29$ & 14 \\
\hline $624.61-2,691.58$ & 11 \\
\hline \multicolumn{2}{|l|}{ Region of origin } \\
\hline Metropolitan Region of Belo Horizonte & 50 \\
\hline Countryside of the State of Minas Gerais & 50 \\
\hline \multicolumn{2}{|l|}{ Absence from work due to $\mathrm{CL}$} \\
\hline Yes & 56 \\
\hline No & 44 \\
\hline \multicolumn{2}{|l|}{ Hospitalization due to $\mathrm{CL}$} \\
\hline Yes & 9 \\
\hline No & 81 \\
\hline \multicolumn{2}{|l|}{ Amount of residents in the same household } \\
\hline One & 8 \\
\hline Two or three & 51 \\
\hline Four or five & 34 \\
\hline Six or more & 7 \\
\hline
\end{tabular}

(continues) 
Table 1 (continued)

\begin{tabular}{lc}
\hline Characteristics & $\mathbf{N}=\mathbf{1 0 0}$ \\
\hline $\begin{array}{l}\text { Health insurance } \\
\text { Yes }\end{array}$ & 38 \\
No & 62 \\
Disease severity & \\
$\quad$ Number of lesions & 69 \\
$\quad$ One lesion & 31 \\
$\quad$ More than two lesions & 83 \\
Lesion appearance & 17 \\
$\quad$ Ulcerative & 52 \\
$\quad$ Non-ulcerative & 48 \\
Therapy & \\
Meglumine antimoniate Intralesional & \\
Meglumine antimoniate Intravenous & \\
\hline * Totals vary due to missing data; & \\
** The income range was elaborated according to economic classes (A, B, C, D and E), proposed by the Center for Social \\
Policy, Getúlio Vargas Foundation, Brazil (https://cps.fgv.br/qual- income-family-of-classes).
\end{tabular}

Table 2

Economic aspects and direct medical and non-medical costs from the perspective of cutaneous leishmaniasis patients attended at the reference center for the disease $(N=100)$.

\begin{tabular}{|c|c|c|c|c|c|}
\hline & Mean & SD & Median & IQR & Maximum \\
\hline Per capita income (USD) & 347.39 & 326.41 & 259.60 & $120.71-467.29$ & $1,557.63$ \\
\hline Family income (USD) & $1,012.07$ & 979.15 & 778.81 & 373.83-1,093.45 & $4,984.42$ \\
\hline \multicolumn{6}{|l|}{ Expenses with } \\
\hline Medical consultations & 19.25 & 55.49 & 0.00 & $0.00-0.00$ & 311.52 \\
\hline Health insurance co-participation & 20.07 & 63.25 & 0.00 & $0.00-0.00$ & 404.98 \\
\hline Medical examinations & 15.80 & 37.33 & 0.00 & $0.00-6.23$ & 218.06 \\
\hline Medications & 28.23 & 52.43 & 0.00 & $0.00-31.15$ & 311.52 \\
\hline Hospitalization & 0.00 & 0.00 & 0.00 & $0.00-0.00$ & 0.00 \\
\hline Dressing materials & 9.37 & 16.26 & 0.00 & $0.00-15.57$ & 93.45 \\
\hline Transportation & 51.15 & 63.76 & 31.15 & $0.00-71.65$ & 311.52 \\
\hline Out-of-home meals & 33.95 & 36.26 & 31.15 & $0.00-62.30$ & 155.76 \\
\hline Caregiver for patient/children & 0.00 & 0.00 & 0.00 & $0.00-0.00$ & 0.00 \\
\hline Domestic outsourcing & 5.40 & 35.51 & 0.00 & $0.00-0.00$ & 311.52 \\
\hline Business outsourcing & 13.42 & 66.99 & 0.00 & $0.00-0.00$ & 498.44 \\
\hline Total & 187.32 & 184.62 & 125.38 & $51.40-291.27$ & 834.89 \\
\hline
\end{tabular}

IQR: interquartile range; SD: standard deviation. 


\section{Figure 1}

Direct medical and non-medical costs associated with cutaneous leishmaniasis diagnosis and treatment $(\mathrm{N}=100)$.

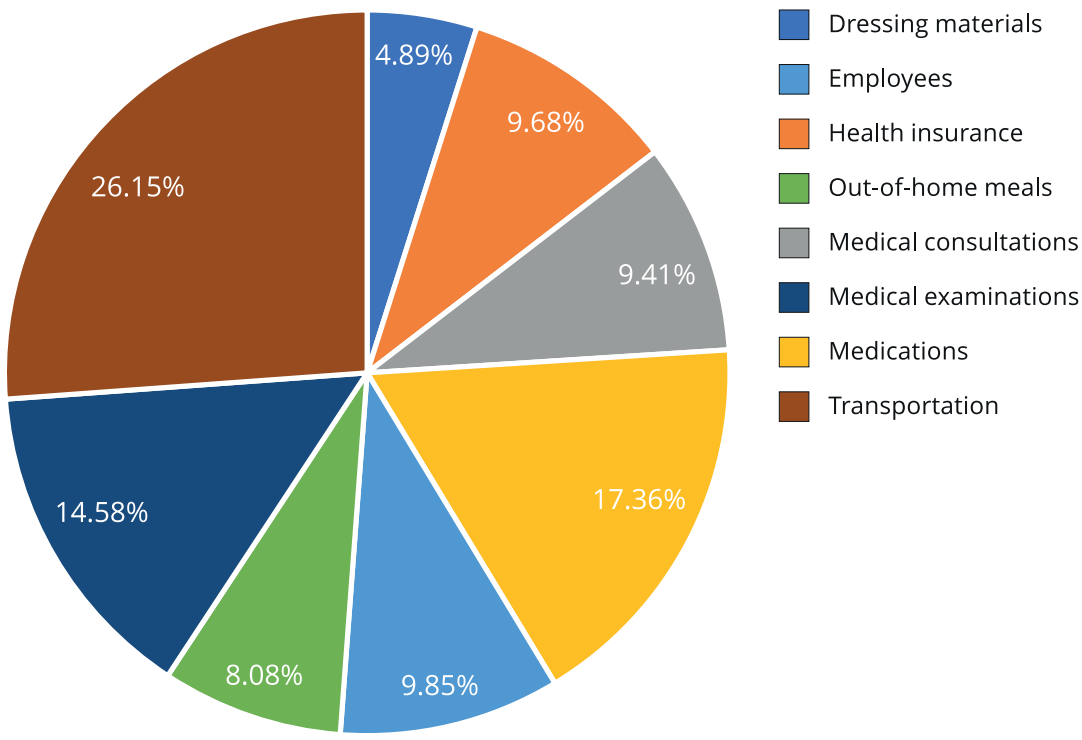

Patients over 50 years old spent more on medications and domestic and business outsourcing services than younger patients; women also reported more expenses on these services than men. Our analyzes showed that patients with a per capita income greater than Brazilian minimum wage were who spent more on outsourcing services and co-participation in private health insurances. Patients who traveled more than $30 \mathrm{~km}$ to obtain a CL diagnosis reported higher expenses with food than patients who traveled smaller distances; this result did no expand to treatment-related dislocations. Cost estimation of medication and medical exams were higher for patients who reported having had more than six medical appointments. Medical exams costs were higher for patients undergoing intravenous treatment than intralesional infiltration. Tables 3 and 4 show the results of the association tests between the distribution of direct medical and non-medical costs and CL sociodemographic variables, clinical aspects, and healthcare. 
Table 3

Subgroup comparisons on illness total costs (medical appointments, medical examinations, medications, transportation, out-of-home meals) and sociodemographic, clinical and healthcare aspects.

\begin{tabular}{|c|c|c|c|c|c|c|c|c|c|c|}
\hline \multirow[t]{3}{*}{ Characteristics } & \multicolumn{10}{|c|}{ Expenses with } \\
\hline & \multicolumn{2}{|c|}{ Medical appointments } & \multicolumn{2}{|c|}{ Medical examinations } & \multicolumn{2}{|c|}{ Medications } & \multicolumn{2}{|c|}{ Transportation } & \multicolumn{2}{|c|}{ Out-of-home meals } \\
\hline & Mean (SD) & p-value & Mean (SD) & p-value & Mean (SD) & p-value & Mean (SD) & p-value & Mean (SD) & p-value \\
\hline \multicolumn{11}{|l|}{ Gender } \\
\hline Male & $24.85(64.04)$ & 0.357 & $17.68(40.75)$ & 0.514 & $25.14(44.65)$ & 0.708 & $52.72(68.06)$ & 0.941 & 34.55 (37.70) & 0.921 \\
\hline Female & $4.92(15.21)$ & & $11.22(27.46)$ & & $35.82(68.32)$ & & $47.33(52.81)$ & & $32.48(33.11)$ & \\
\hline \multicolumn{11}{|l|}{ Age (years) } \\
\hline Up to 50 & $13.21(45.47)$ & 0.159 & $13.70(36.65)$ & 0.603 & $19.19(48.28)$ & 0.009 * & $44.91(53.02)$ & 0.296 & $36.09(37.00)$ & 0.456 \\
\hline Over 50 & $29.33(68.60)$ & & $19.28(38.72)$ & & $43.52(56.21)$ & & $62.03(78.78)$ & & $30.37(35.21)$ & \\
\hline \multicolumn{11}{|l|}{$\begin{array}{l}\text { Per capita income } \\
\text { (BRL) }\end{array}$} \\
\hline Up to 937.00 & $10.20(35.01)$ & 0.697 & $10.64(30.41)$ & 0.501 & $24.19(45.73)$ & 0.364 & $48.31(55.90)$ & 0.950 & $37.14(37.81)$ & 0.179 \\
\hline Over 937.00 & 26.65 (73.31) & & 21.76 (46.77) & & $24.71(40.67)$ & & $58.36(77.43)$ & & 27.78 (34.27) & \\
\hline \multirow{2}{*}{\multicolumn{11}{|c|}{$\begin{array}{l}\text { Highest education } \\
\text { level completed }\end{array}$}} \\
\hline & & & & & & & & & & \\
\hline $\begin{array}{l}\text { Primary education } \\
\text { or lower }\end{array}$ & 23.09 (57.03) & 0.419 & $18.57(42.97)$ & 0.784 & $25.85(46.47)$ & 0.971 & $43.76(56.84)$ & 0.215 & $38.71(38.97)$ & 0.443 \\
\hline Secondary school & $12.93(61.09)$ & & $13.64(32.23)$ & & $28.57(45.10)$ & & $43.97(39.21)$ & & $27.78(27.65)$ & \\
\hline Higher education & $17.30(43.03)$ & & $10.62(24.77)$ & & $34.26(75.25)$ & & $80.83(95.87)$ & & $29.01(38.36)$ & \\
\hline \multicolumn{11}{|l|}{$\begin{array}{l}\text { Distance traveled for } \\
\text { diagnosis }\end{array}$} \\
\hline Up to $30 \mathrm{~km}$ & $19.40(62.04)$ & 0.470 & $9.99(21.67)$ & 0.730 & $27.85(43.41)$ & 0.556 & $31.33(31.21)$ & 0.137 & 21.49 (33.77) & $0.003^{*}$ \\
\hline Over 30km & $19.17(51.91)$ & & $19.30(43.66)$ & & $28.43(57.23)$ & & $62.53(74.33)$ & & 41.09 (35.95) & \\
\hline \multicolumn{11}{|l|}{$\begin{array}{l}\text { Distance traveled for } \\
\text { treatment }\end{array}$} \\
\hline Up to $30 \mathrm{~km}$ & $18.71(56.32)$ & 0.645 & $16.90(33.89)$ & 0.177 & $36.47(61.41)$ & 0.139 & $40.66(39.86)$ & 0.707 & 89.19 (97.35) & 0.096 \\
\hline Over 30km & 20.04 (55.05) & & $14.17(42.28)$ & & $16.47(33.30)$ & & $65.84(85.34)$ & & $136.70(135.24)$ & \\
\hline \multicolumn{11}{|l|}{$\begin{array}{l}\text { Appointments } \\
\text { amount }\end{array}$} \\
\hline Up to five & $10.87(40.79)$ & 0.119 & 9.67 (35.47) & $0.012^{*}$ & 7.90 (20.96) & $<0.001$ * & $46.15(66.38)$ & 0.155 & $103.30(123.69)$ & 0.395 \\
\hline Over five & $27.25(67.24)$ & & $21.76(37.25)$ & & $48.75(66.30)$ & & $56.58(62.76)$ & & $119.72(110.78)$ & \\
\hline \multicolumn{11}{|l|}{ Therapy } \\
\hline $\begin{array}{l}\text { Meglumine } \\
\text { antimoniate } \\
\text { intralesional }\end{array}$ & $16.80(41.59)$ & 0.461 & $11.54(36.36)$ & $0.048^{*}$ & $32.51(61.93)$ & 0.731 & $43.28(44.33)$ & 0.786 & $120.54(118.31)$ & 0.305 \\
\hline $\begin{array}{l}\text { Meglumine } \\
\text { antimoniate } \\
\text { intravenous }\end{array}$ & $21.61(66.52)$ & & $20.05(38.19)$ & & $24.20(41.84)$ & & $58.40(77.24)$ & & $98.36(114.78)$ & \\
\hline
\end{tabular}

SD: standard deviation.

Note: costs are presented in American Dollar (USD).

$* \mathrm{p}<0.05$. 
Table 4

Subgroup comparisons on illness total costs (domestic and business outsourcing services, dressing materials, health insurance co-participation, total expenses) and sociodemographic, clinical and healthcare aspects.

\begin{tabular}{|c|c|c|c|c|c|c|c|c|c|c|}
\hline \multirow[t]{3}{*}{ Characteristics } & \multicolumn{10}{|c|}{ Expenses with } \\
\hline & \multicolumn{2}{|c|}{ Domestic outsourcing } & \multicolumn{2}{|c|}{ Business outsourcing } & \multicolumn{2}{|c|}{ Dressing materials } & \multicolumn{2}{|c|}{$\begin{array}{l}\text { Health insurance } \\
\text { co-participation }\end{array}$} & \multicolumn{2}{|c|}{ Total expenses } \\
\hline & Mean (SD) & p-value & Mean (SD) & p-value & Mean (SD) & p-value & Mean (SD) & p-value & Mean (SD) & p-value \\
\hline \multicolumn{11}{|l|}{ Gender } \\
\hline Male & 0.00 & 0.007 * & $17.37(77.38)$ & 0.597 & $9.14(16.60)$ & 0.762 & $16.52(61.63)$ & 0.107 & $187.24(187.18)$ & 0.932 \\
\hline Female & $18.26(64.23)$ & & $4.29(23.13)$ & & $9.93(15.69)$ & & $30.74(68.26)$ & & $187.53(181.14)$ & \\
\hline \multicolumn{11}{|l|}{ Age (years) } \\
\hline Up to 50 & 0.00 & 0.025 * & $6.48(37.53)$ & 0.280 & $7.73(14.50)$ & 0.187 & $9.28(40.02)$ & 0.032 & $139.47(147.53)$ & 0.003 * \\
\hline Over 50 & $14.31(57.15)$ & & $24.97(96.04)$ & & $12.08(18.71)$ & & $39.90(89.36)$ & & $271.76(213.62)$ & \\
\hline \multicolumn{11}{|l|}{$\begin{array}{l}\text { Per capita income } \\
\text { (BRL) }\end{array}$} \\
\hline Up to 937.00 & 0.00 & 0.042 * & $11.35(55.67)$ & 0.445 & $9.53(17.95)$ & 0.749 & $5.30(36.35)$ & 0.001 * & $145.16(136.91)$ & 0.065 \\
\hline Over 937.00 & $14.31(57.15)$ & & $19.78(85.20)$ & & $7.44(12.63)$ & & $42.91(87.45)$ & & $238.90(211.13)$ & \\
\hline \multicolumn{11}{|l|}{$\begin{array}{l}\text { Highest education } \\
\text { level completed }\end{array}$} \\
\hline $\begin{array}{l}\text { Primary education } \\
\text { or lower }\end{array}$ & $2.93(21.39)$ & 0.101 & $17.28(80.41)$ & 0.946 & 10.99 (19.05) & 0.245 & $8.54(34.47)$ & 0.078 & $178.42(197.84)$ & 0.286 \\
\hline Secondary school & 0.00 & & $10.59(52.95)$ & & $5.33(11.11)$ & & 33.85 (92.94) & & $170.15(154.25)$ & \\
\hline Higher education & 19.67 (72.09) & & $6.55(28.58)$ & & $10.41(13.13)$ & & $37.38(77.61)$ & & $236.56(185.78)$ & \\
\hline \multicolumn{11}{|l|}{$\begin{array}{l}\text { Distance traveled for } \\
\text { diagnosis }\end{array}$} \\
\hline Up to $30 \mathrm{~km}$ & $15.13(58.70)$ & 0.019 * & $14.23(84.24)$ & 0.458 & $9.92(13.15)$ & 0.142 & $39.17(73.60)$ & 0.014 * & $183.20(164.34)$ & 0.900 \\
\hline Over $30 \mathrm{~km}$ & 0.00 & & $12.95(84.24)$ & & $9.07(17.85)$ & & $11.16(56.27)$ & & $189.66(196.48)$ & \\
\hline \multicolumn{11}{|l|}{$\begin{array}{l}\text { Distance traveled for } \\
\text { treatment }\end{array}$} \\
\hline Up to $30 \mathrm{~km}$ & $29.82(148.76)$ & 0.138 & $65.54(268.46)$ & 0.328 & $35.17(61.08)$ & 0.489 & $23.65(58.75)$ & 0.231 & $197.12(199.21)$ & 0.711 \\
\hline Over 30km & 0.00 & & $10.25(64.05)$ & & $23.04(36.03)$ & & $15.57(69.01)$ & & $172.87(162.24)$ & \\
\hline \multicolumn{11}{|l|}{$\begin{array}{l}\text { Appointments } \\
\text { amount }\end{array}$} \\
\hline Up to five & $13.46(74.17)$ & 0.693 & $55.88(256.25)$ & 0.416 & $23.46(44.44)$ & 0.060 & $16.34(64.02)$ & 0.861 & $150.26(160.45)$ & 0.053 \\
\hline Over five & 23.25 (152.49) & & $22.28(144.42)$ & & $37.32(60.41)$ & & $18.17(56.89)$ & & 215.75 (184.39) & \\
\hline \multicolumn{11}{|l|}{ Therapy } \\
\hline $\begin{array}{l}\text { Meglumine } \\
\text { antimoniate } \\
\text { intralesional }\end{array}$ & $25(146.59)$ & 0.536 & $44.50(186.00)$ & 0.662 & $35.52(61.65)$ & 0.583 & $10.61(44.53)$ & 0.112 & $184.80(191.94)$ & 0.961 \\
\hline $\begin{array}{l}\text { Meglumine } \\
\text { antimoniate } \\
\text { intravenous }\end{array}$ & $10.00(70.71)$ & & $41.66(235.85)$ & & $24.90(41.15)$ & & $29.52(77.00)$ & & $189.84(179.05)$ & \\
\hline
\end{tabular}

SD: standard deviation.

Note: costs are presented in American Dollar (USD).

$* p<0.05$. 


\section{Discussion}

In Brazil, the Brazilian's Unified National Health System (SUS) diagnoses and treats CL, covering all direct medical costs 12 . This study identified patients' expenses with private health services (medical appointments and co-participation in private health insurances), medication, medical exams, and dressing material. CL also leads to direct non-medical costs, such as transportation to health centers, food, and domestic and business outsourcing services. The participants of this study reported no expenses with hospitalization and caregivers for themselves or their children.

In this study, the median total cost with CL was USD 125.38, much higher than that found by an economic evaluation study conducted in Sri Lanka (USD 66.85) 8. Considering Brazil minimum wage at the period of data collection, equivalent to USD 283.02 (BRL 908.05), CL average monthly cost of USD 133.80 (BRL 429.50) may represent a significant economic loss for patients. The difference in costs with CL between Brazil and Sri Lanka may be attributed to the different values of products and services 13 .

Patients living in lower-income countries have significant healthcare expenses ${ }^{14}$. In our study, although only few patients had private health insurances, the highest direct medical cost was on coparticipation in it. Despite the financial burden caused by hiring these services, patients continued to depend on the public health system (as all participants were referred to the Leishmaniasis Reference Center, which is a public health center). In Brazil, health insurance companies dispose of the legal obligation to refund the expenses of the Brazilian public health system in the eventual attendance of their beneficiaries 15 , which does not minimize the financial burden in a societal perspective.

Transport and food comprised the higher direct non-medical costs; expenses on food were associated with traveled distance for CL diagnosis, which is corroborated by prior studies, that reported an increase in CL expenses due to travel demand 8,14 . The low resolubility of the primary health care of the state of Minas Gerais in caring and managing patients with CL signs, verified by this study, may increase these expenses. The number of medical appointments until CL diagnostic confirmation and the need to refer patients to a specialized health center indicate the low resolution of the public health system, or at least the incapacity of the primary health care services in recognizing CL. Secondary health care should support diagnose and therapy only in most complicated cases. Thus, to minimize the patients' expenses, Family Health Strategie must prioritize preparing clearer healthcare protocols by defining referral flows, so to meet health demands in a resolute, equitable, and universal strategy. Considering our research backdrop and that food-related direct non-medical costs have been previously reported by other authors 16,17,18, the public policies should acknowledge our findings, as food is a refundable cost 17 .

Our study indicated that $76 \%$ of patients required at least three medical appointments before receiving CL diagnostic confirmation, which may be related to the inability of professionals on suspecting of $\mathrm{CL}$ at the first appointment. This lack have been identified by a previous study that evaluated the diagnosis and treatment of visceral leishmaniasis in Belo Horizonte metropolitan area 19. Health managers should pay special attention to professionals inability in performing CL diagnostic exams, especially in the primary health care centers 20 . The differential diagnosis of CL are still challenging for physicians because of the wide number of dermatological diseases with similar clinical manifestations 21 and the lack of access to material and technical resources (including the Montenegro test, surgical material, and resources for biopsy and parasitological examination). Moreover, the scarcity of electrocardiogram and laboratory equipment to perform the necessary tests for monitoring toxicity hampers patients' treatment near their home.

These results point to an inefficient diagnose and treatment of CL in Minas Gerais. Using a participative strategy to structure assistance policies in primary health centers may favor rapid and decentralized diagnosis, by ensuring the adherence and efficiency of staff members, as well as their training. Such action can reduce leishmaniasis morbidity in Brazil 22 and economic impact 3,23.

Yet, a study showed impasses in implementing fast diagnostic tests for visceral leishmaniasis in health services of an endemic municipality: health professionals refused to perform the rapid test during trainings; rapid tests presented problems in purchase and delay in the delivery; both patients and health professionals reported problems in collecting capillary blood; professionals in health care centers were unclear about their duties and responsibilities; and patients evaded to bigger cities 22 . 
Not addressing these demands to the health department will cause the continued burden to the more complex health care services and generate financial costs for both the patient and the health care system. Consistent and continuous policies are needed to improve these points.

In this study, the costs of medical exams were statistically higher for patients undergoing intravenous treatment (USD 20.05) than intralesional (USD 11.54). We included patients who were participating in a clinical trial to evaluate the efficacy and safety of a standard intralesional infiltration technique of meglumine antimoniate for CL treatment, in which weekly tests composed the protocol 24. Regardless of the chosen treatment, our results showed that although the public health system guarantees coverage of costs related to additional tests for monitoring an individual being treated in the SUS, patients reported expenses on this demand. The expenditure on laboratory exams may reveal the deficiency of the public health infrastructure for an appropriate approach for CL 25 . Costeffectiveness studies comparing these therapeutic options may complement our analyzes and support the recommendations.

Our study showed that CL led to productivity loss regarding work absences and inability to perform housework, increasing the mean economic impact for patients, as previously reported in a study conducted in Afghanistan 14. Women reported higher expenses on hiring people to perform housework than men, certainly related to the social roles assigned for each gender 26. In Afghanistan, the social impact of CL provoke the loss of women productivity once, after being infected, they are prevented from cooking, marrying, and having children 23 . Our study lacks enough data to conclude whether productivity loss is associated with physical disability or with the demand to attend health services for medical appointments and treatment.

The inability to work increases the total costs of the disease 27. In our study, we estimated no indirect costs for work absence and retirement as loss of productivity (the amount of loss within the patient's wage that was not earned due to illness absence at work). This is justified because, in Brazil, the employer or Social Security pay for the absences justified by illness of those who have a formal job. We also estimated no possible costs with a multidisciplinary team, such as psychologists, nurses, and physiotherapists, which play a role in the recovery of the patients' quality of life. Studies including these variables may verify the real demand for these professionals and guide the primary health care system in providing these services. Our results do not allow to conclude that the costs generated by CL impoverished families due to financial commitment. However, we cannot underestimate patients' expenses with CL, which corresponded on average to half of the household income. Further studies with a longitudinal design should be conducted to solve this issue and decrease the chance of participants' recall bias. Qualitative studies could support strategies for reducing economic loss and improving the way through which specific groups of patients deal with the disease.

This study has some limitations. As the reported expenses were related to the interview moment, not all patients were in the same stage of the treatment. As this study was conducted only in one CL reference center, the patients included may not represent other patients affected by CL, so results cannot be generalized; similarly, the reported expenses of the patients in this study may not be representative for another region. As we included only adult patients, the evaluated costs should not be expanded for children affected by CL. Recall bias, inherent to the retrospective nature of the covered topics, may have influenced some results. We found some difficulties in collecting data on the income variable: $11 \%$ of the patients did not answer to this question. Yet, this study points out relevant results for the discussion of the economic impact of CL in patients.

CL-related costs can ascertain delay in diagnosis and even underreporting of the disease, as well as less adherence to treatments. Thus, strategies focusing on this disease should consider reducing patients' displacement and personal expenses. Economic impact may be reduced by decentralizing diagnosis and treatment, improving health services, and ensuring early and accurate diagnosis and appropriate treatment where patients live and work.

Considering the low-income status of the study group, the CL-related expenses may represent an economic impact on patients' lives. Despite the aforementioned limitations, we expect these results to guide public health policies to provide the basic necessities of CL patients; our results indicate as the main one the decentralization of human and material resources for CL diagnosis and therapeutic approach. 


\section{Contributors}

E. L. Galvão participated in the conceptualization, formal analysis, methodology, writing the original draft and final approval of the version to be submitted. T. S. M. Assis contributed in the methodology, writing (review and editing) and final approval of the version to be submitted. M. J. Pedras participated in the investigation, methodology and final approval of the version to be submitted. G. F. Cota contributed in the supervision, methodology, writing (review and editing) and final approval of the version to be submitted. T. C. Simões collaborated in the supervision, methodology, review and editing of the article and final approval of the version to be submitted. A. Rabello participatde in the conceptualization, investigation, methodology, supervision, review and editing of thye article and final approval of the version to be submitted.

\section{Additional informations}

ORCID: Endi Lanza Galvão (0000-0002-56483932); Talia Santana Machado de Assis (00000002- 5682-2981); Mariana Junqueira Pedras (0000-0003-2494-6178); Gláucia Fernandes Cota (0000-0003-0538-7403); Taynãna César Simões (0000-0002-5849-343X); Ana Rabello (0000-00015821-4069).

\section{Conflict of interests}

The authors declare no conflict of interest.

\section{Acknowledgments}

We offer our deepest thanks to the René Rachou Institute, Oswaldo Cruz Foundation, that provided technical support for the development and implementation of this study, and to Brazilian National Research Council (CNPq) and Minas Gearais State Research Foundation (FAPEMIG) for the financial support.

\section{References}

1. Alvar J, Vélez ID, Bern C, Herrero M, Desjeux $\mathrm{P}$, Cano J, et al. Leishmaniasis worldwide and global estimates of its incidence. PLoS One 2012; 7:e35671.

2. World Health Organization. Neglected tropical diseases. http://www.who.int/neglected_ diseases/diseases/en/ (accessed on 02/Feb/ 2018).

3. Reithinger R. Leishmaniases' burden of disease: ways forward for getting from speculation to reality. PLoS Negl Trop Dis 2008; 2:e285.

4. Bailey F, Mondragon-Shem K, Hotez P, RuizPostigo JA, Al-Salem W, Acosta-Serrano A, et al. A new perspective on cutaneous leishmaniasis: implications for global prevalence and burden of disease estimates. PLoS Negl Trop Dis 2017; 11:e0005739.

5. Karimkhani C, Wanga V, Coffeng LE, Naghavi P, Dellavalle RP, Naghavi M. Global burden of cutaneous leishmaniasis: a cross-sectional analysis from the Global Burden of Disease Study 2013. Lancet Infect Dis 2016; 16:584-91.

6. Mashayekhi-Ghoyonlo V, Kiafar B, Rohani M, Esmaeili H, Erfanian-Taghvaee MR. Correlation between socioeconomic status and clinical course in patients with cutaneous leishmaniasis. J Cutan Med Surg 2015; 19:40-4.

7. Okwor I, Uzonna J. Social and economic burden of human leishmaniasis. Am J Trop Med Hyg 2016; 94:489-93.

8. Wijerathna T, Gunathilaka N, Gunawardena $\mathrm{K}$. The economic impact of cutaneous leishmaniasis in Sri Lanka. Biomed Res Int 2018; (5)3025185.

9. Sunyoto T, Boelaert M, Meheus F. Understanding the economic impact of leishmaniasis on households in endemic countries: a systematic review. Expert Rev Anti Infect Ther 2019; 17:57-69.

10. Galvão EL, Pedras MJ, Cota GF, Simões TC, Rabello A. Development and initial validation of a cutaneous leishmaniasis impact questionnaire. PLoS One 2018; 13:e0203378.

11. Galvão EL, Pedras MJ, Cota GF, Rabello A, Simões TC. How cutaneous leishmaniasis and treatment impacts in the patients' lives: a cross-sectional study. PLoS One 2019; 14:e0211374.

12. Departamento de Vigilância Epidemiológica, Secretaria de Vigilância em Saúde, Ministério da Saúde. Manual de vigilância da leishmaniose tegumentar americana. Brasília: Editora do Ministério da Sáude; 2013.

13. Precios Mundi. Comparação de preços Brasil vs. Sri Lanka. https://pt.preciosmundi.com/ comparar? country=brasil\&vs Country $=$ srilanka\&category=all\&currency=USD (accessed on 10/Apr/2019).

14. Stahl H-C, Ahmadi F, Nahzat SM, Dong H-J, Stahl K-W, Sauerborn R. Health economic evaluation of moist wound care in chronic cutaneous leishmaniasis ulcers in Afghanistan. Infect Dis Poverty 2018; 7:12. 
15. Brasil. Lei no 9.656, de 3 de junho de 1998. Dispõe sobre os planos e seguros privados de assistência à saúde. Diáfio Oficial da União 1988; 4 jun.

16. Teni FS, Gebresillassie BM, Birru EM, Belachew SA, Tefera YG, Wubishet BL, et al. Costs incurred by outpatients at a university hospital in northwestern Ethiopia: a crosssectional study. BMC Health Serv Res 2018; 18:842.

17. Daga S, Mhatre S, Dsouza E. Out-of-pocket nonmedical expenses associated with out-patient treatment of common childhood illnesses. J Trop Pediatr 2015; 61:226-8.

18. Tibebe A, Amarech G, Melesse T, Mariam DH. Examining out of pocket payments for maternal health in rural Ethiopia: Paradox of free health care un-affordability. Ethiop J Health Dev 2012; 26:251-7.

19. Luz ZMP, Carneiro M, Schall V, Rabello A. The organization of health services and visceral leishmaniasis: an integrated intervention to improve diagnosis and treatment. Cad Saúde Pública 2009; 25:1177-84.

20. Lima MVN, Oliveira RZ, Lima AP, Felix MLO, Silveira TGV, Rossi RM, et al. Atendimento de pacientes com leishmaniose tegumentar americana: avaliação nos serviços de saúde de municípios do noroeste do Estado do Paraná, Brasil. Cad Saúde Pública 2007; 23:2938-48.

21. Tirelli F, Vernal S, Roselino AM, Tirelli F, Vernal S, Roselino AM. Final diagnosis of 86 cases included in differential diagnosis of American tegumentary leishmaniasis in a Brazilian sample: a retrospective cross-sectional study. An Bras Dermatol 2017; 92:642-8.
22. Assis TM, Guimarães PN, Oliveira E, Peruhype-Magalhães V, Gomes LI, Rabello A, et al. Acceptance and potential barriers to effective use of diagnostic tests for visceral leishmaniasis in an urban area in Brazil. Rev Soc Bras Med Trop 2016; 49:241-4.

23. Reithinger R, Aadil K, Kolaczinski J, Mohsen M, Hami S. Social impact of leishmaniasis, Afghanistan. Emerg Infect Dis 2005; 11:634-6.

24. Ramalho DB. Estudo clínico para avaliação da eficácia e segurança do uso intralesional de antimoniato de meglumina no tratamento da leishmaniose cutânea localizada [Dissertação de Mestrado]. Belo Horizonte: Instituto René Rachou, Fundação Oswaldo Cruz; 2018.

25. Luz ZMP, Pimenta DN, Cabral ALLV, Fiúza VOP, Rabello A. A urbanização das leishmanioses e a baixa resolutividade diagnóstica em municípios da Região Metropolitana de Belo Horizonte. Rev Soc Bras Med Trop 2001; 34:249-54.

26. Velez ID, Hendrickx E, Robledo SM, Agudelo SP. Leishmaniosis cutánea en Colombia y género. Cad Saúde Pública 2001; 17:171-80.

27. Azevedo VF, Rossetto CN, Lorencetti PG, Tramontin MY, Fornazari B, Araújo DV. Custos diretos e indiretos do tratamento de pacientes com espondilite anquilosante pelo sistema público de saúde brasileiro. Rev Bras Reumatol 2016; 56:131-7. 


\section{Resumo}

A leishmaniose cutânea (LC) é uma doença associada a populações de baixa renda. Portanto, a inclusão do impacto financeiro sobre os pacientes é muito importante para avaliar a carga dessa doença. Tivemos como objetivo avaliar o impacto econômico da LC em pacientes afetados pela doença e tratados em um centro de referência para $L C$ no Estado de Minas Gerais, Brasil. Foi um estudo transversal com base em análise de entrevistas e prontuários médicos para compilação dos gastos médicos e não médicos diretos relacionados à $L C$, desde uma perspectiva societal. Foram incluidos cem pacientes; $50 \%$ tinham renda mensal per capita de até USD 259,60. O gasto médio na doença foi de USD 187,32, o que representa um impacto mensal médio de 22,5\% (USD 133,80). A doença impôs custos médicos diretos, como o pagamento por consultas médicas particulares, exames médicos, material para curativos e co-participação em seguro de saúde. Os custos não médicos diretos estiveram relacionados ao transporte dos pacientes até os centros de saúde, cuidados adicionais, alimentação e contratos com serviços terceirizados para atividades domésticas e laborais. O transporte dos pacientes para as consultas médicas representava a principal parcela dos gastos (USD 4.911,00). Embora o acesso à assistência à saúde seja um direito garantido pelo Sistema Único de Saúde, a LC ainda gera um impacto financeiro substancial para os pacientes. A descentralização dos serviços diagnósticos e terapêuticos para LC e o aumento de sua eficiência são as principais medidas que podem reduzir os gastos com essa doença.

Leishmaniose Cutânea; Efeitos Piscossociais da Doença; Avaliação em Saúde

\section{Resumen}

La leishmaniosis cutánea (LC) es una enfermedad asociada a poblaciones con ingresos bajos. Por ello, incluir el impacto financiero para las personas es muy importante a la hora de evaluar la carga de esta enfermedad. Nuestro objetivo fue evaluar el impacto económico de la $L C$, de pacientes afectados por esta enfermedad, que fueron tratados por un servicio de referencia para el tratamiento de la LC en el Estado de Minas Gerais, Brasil. Este estudio transversal basado en entrevistas y análisis de registros médicos para la recopilación de gastos médicos y no-médicos directos, relacionados con la $L C$ desde una a perspectiva social. Se incluyeron a cien pacientes; el 50\% contaba con ingresos mensuales per cápita de hasta USD 259,60 y gastaban un promedio de USD 187,32 en la enfermedad, representando un impacto promedio mensual de 22,5\% (USD 133,80). La enfermedad supuso costes médicos directos, como el pago de citas médicas privadas, medicamentos, exámenes médicos, material para vendajes, y coparticipación en seguros médicos. Los costes directos no-médicos estaban relacionados con el transporte de los pacientes a los centros de salud, el cuidado necesario, comida, y contratos con servicios externalizados para actividades domésticas y laborales. El transporte de los pacientes para citas médicas representó la principal razón para los gastos (USD 4.911,00). A pesar de que el acceso a los cuidados de salud es un derecho garantizado por el sistema de salud público brasileño, la LC todavía supone un impacto financiero importante para los pacientes. La descentralización de los servicios para el diagnóstico de LC, la aproximación terapéutica, y el incremento de su eficiencia, son las acciones con principal potencial para reducir los gastos financieros de esta enfermedad.

Leishmaniasis Cutánea; Costo de Enfermedad; Evaluación en Salud
Submitted on $19 / \mathrm{Jul} / 2019$

Final version resubmitted on 06/Nov/2019

Approved on 06/Dec/2019 